\title{
Halophytes as components of lawns under different soil salinity and human impact in the health resort "Ciechocinek"
}

\author{
*Andrzej Nienartowicz, *Agnieszka Piernik, *Joanna Marcykiewicz, *Marta Lis, \\ **Mieczyslaw Kunz, ***Silvio Viglia \\ *Institute of Ecology and Protection of Environment, Nicolaus Copernicus University, \\ Gagarina 9, 87-100 Toruń, Poland \\ e-mail: anienart@umk.pl, \\ **Institute of Geography, Nicolaus Copernicus University, Gagarina 9, 87-100 Toruń, Poland, \\ ****Parthenope, University of Naples, Department of Sciences for the Environment \\ Centro Direzionale, Isola C4, 80143 Napoli, Italy
}

\begin{abstract}
Summary. The comparison was performed on the flora of lawns located in the vicinity of three brine concentration towers in the Spa Park in the town of Ciechocinek. It was found that a different level of saline water inflow into the soil and a different use of these lawns are the main causes of the observed differences in the number and the species composition of halophytes and glycophytes. The possibility of determining the differences in the intensity of human impact on the studied systems was discussed, as well as the value of the Environmental Sustainability Index was determined through emergy analysis. Energy flow diagrams were prepared for two basic greenery management methods and salt production, which best differentiates the flora of the studied lawns.
\end{abstract}

Key words: spa, green areas, salt production, diversity, halophytes, species composition, numerical classification, energy flow, emergy, ESI.

\section{Introduction}

In temperate climate, the development of halophytes depends on continuous inflow of saline waters. This takes place as a result of natural processes or human activity. The development of halophilous plant communities requires also other, not particularly intensive, disturbances caused by man, which eliminate the presence of more competing plant species. These disturbances are for instance livestock grazing, mowing or trampling down. Among plant communities with some contribution of halophytes, in which the development of halophytes benefits from this kind of actions, one should mention meadows and lawns growing on saline soils in health resorts, where brine is used in therapeutic processes. Both types of communities occur in the health-resort of Ciechocinek in the region of Kujawy in central Poland.

The influence of changes in the intensity of human activities expressed as consumption of cultural energy and energy balance (sensu Odum 1996) on the structure of saline meadows in the reserve of halophytes in Ciechocinek was presented in the previous paper by Nienartowicz (2007). The objective of the researches presented in this paper is to determine how the anthropopressure-related processes of varying intensity influence the populations and the structure of lawns with halophytes situated within this city. 


\section{Location}

Today, the health resort Ciechocinek is a town of 12,000 inhabitants. It is located on the left bank of the Vistula River, about $25 \mathrm{~km}$ in S-E of the city of Torun (Fig. 1). Salt in this region was obtained already in the Middle Ages. In the 13th century, residents of the nearby village of Słońsk (nowadays part of Ciechocinek) drew brine from saline springs and acquired salt using home methods. Drilling works in search for salt deposits in Ciechocinek began in 1791. In the years 1824-1828, saltworks were built here, as well as two graduation towers, i.e. the biggest in Europe wooden constructions for the concentration of low-grade brine. In 1836, four copper bathtubs for brine baths were installed in a local tavern, which were used by 120 persons in the first year of exploitation. This date was accepted as the beginning of the health-resort. In 1847, the construction of new bathrooms with 36 bathtubs was finished, and in 1859 - the construction of the third graduation tower. In the years 1851-1875, the Spa Park was established, the area of which was ca. 70 ha, as well as other green areas. In 1916, Ciechocinek was awarded the city status. In 1932, the opening ceremony of a thermo-brine pool, built between the graduation towers (Fig. 2), was performed by President Mościcki. Until 1950, the health-resort was working only during the summer season (from May to September). Since 1950, the health-resort has been working throughout the year.

The soil is supplied with saline water mainly by three graduation towers located in the Spa Park (Fig. 2). Those are constructions built of 7,000 oak posts rammed into the ground, as well as spruce-pine constructions filled up with blackthorn, over the surface of which brine with a high content of iodine flows down into troughs. Graduation towers have the total length of $1,742 \mathrm{~m}$ (I - $652 \mathrm{~m}$, II - $724 \mathrm{~m}$, III $-366 \mathrm{~m}$ ). Low-grade brine is pumped into graduation towers up to a height of $1 \mathrm{~m}$ with a pipeline from springs situated at a fountain called "Grzyb" from a depth of $409 \mathrm{~m}$ (a wellbore was made in 1911). Today this is done by means of electric pumps, whereas formerly - by means of windmills and steam engines. After 2-3 flows through all graduation towers, after evaporation using the renewable solar energy and wind, $27 \%$ iodine-high-content saline solution is produced from $6 \%$ of brine. Next, the solution is sent by a pipeline from reservoirs under the graduation towers to saltworks located at a distance of ca. $1 \mathrm{~km}$. In the brine concentration process on the graduation towers, a lot of water reaches the ground at the base of the graduation towers bringing about the soil salinity and enabling the development of halophytes.

Staying under the influence of saline waters, lawns near the graduation towers have been permanent research sites since 1986. The vegetation mapping in the direct vicinity of the graduation towers was performed by Handziuk

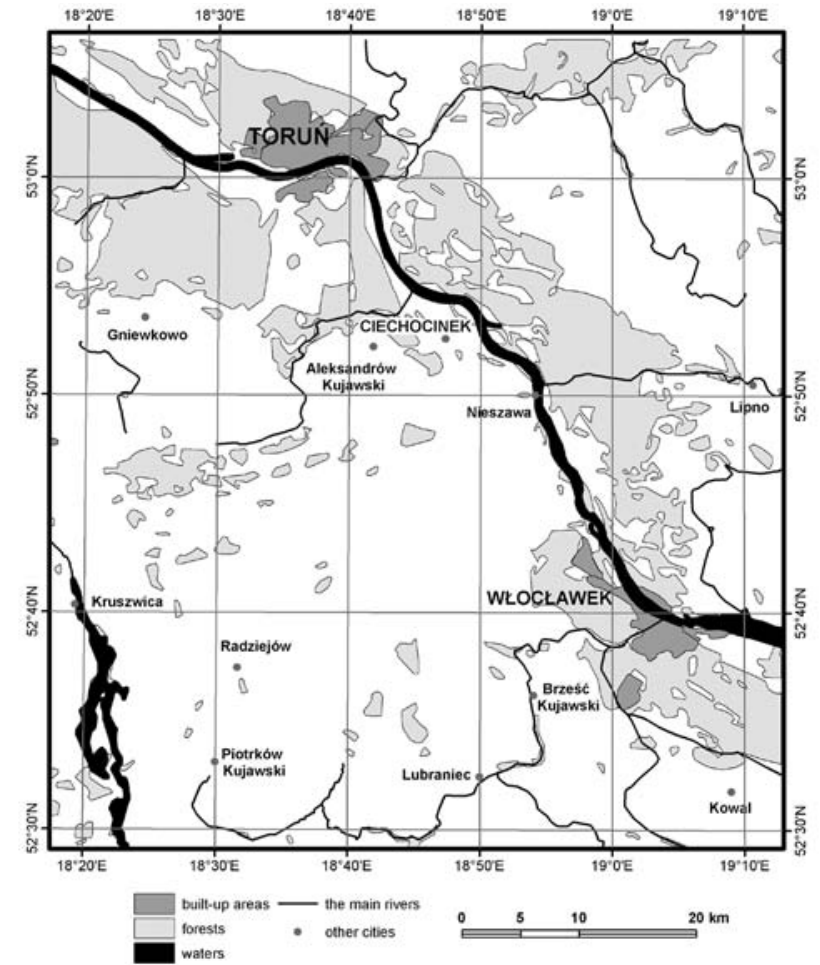

Figure 1. Location of the town and the health-resort Ciechocinek

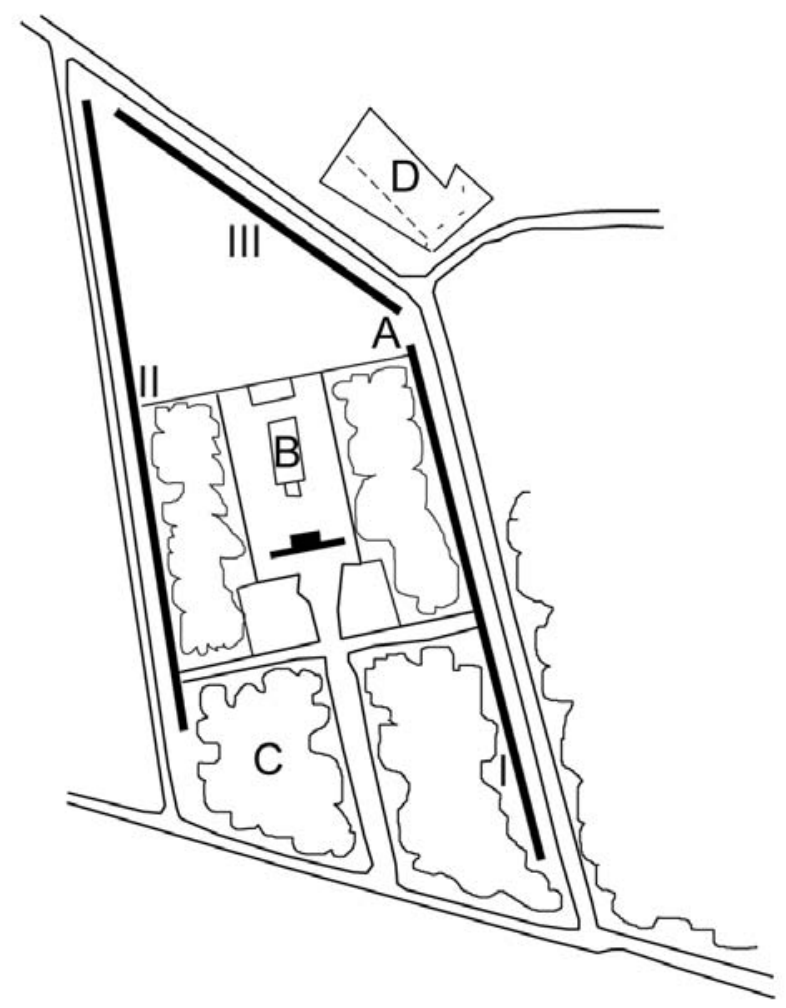

Figure 2. Plan of the Spa Park (A - graduation towers no. I, II and III, B - brine pool, C - tall greenery, D - the nature reserve of halophytes) 
(1988). In 2003 and 2004, the species composition of lawns near the graduation towers was compiled by Marcykiewicz (2004) in the system of permanent research plots.

\section{Methods}

Forms of human activity on the lawns near the graduation towers were defined based on the descriptions included in the papers by Wilkoń-Michalskiej $(1963,1970)$. Data on subsequent management methods applied to these facilities come from our own observations. Changes in the exploitation were presented with the graphical method, in the form of diagrams, prepared with the application of graphical symbols of ,the energy language" introduced by Howard T. Odum (1996). Data on the structure of lawns, coming from the papers by Handziuk (1988) and Marcykiewicz (2005), were collected at plots distributed along the graduation towers, between oak posts supporting the graduation towers. The width of this green belt, measured from the base of a graduation tower and the edge of the pavement, was 6 metres, whereas the distance between the supports ranged from 2 to 7 metres. Along the graduation towers No. I, II and III, research plots 286, 215 and 133 were located, respectively. Some plots by the graduation tower no. 2 were inaccessible.

When comparing the species composition of lawns situated at the base of particular graduation towers, as well as in the studies on the variability of plots in the vicinity of each graduation tower, methods of numerical taxonomy were applied using the software MVSP.

\section{Results}

Based on the analysis of influence exerted by changes in the functioning of the health-resort and saltworks on the structure of lawns near the graduation towers over 25 years, the occurrence of two main situations was observed. The first one occurs with the normal functioning of the graduation towers, the second one - in the situation when a graduation tower is renovated. In the former situation, there is an inflow of saline waters into the substrate, lawns are mown, and the immediate surroundings of the graduation towers are available for visitors (Fig. 3A). In the latter situation (Fig. 3B) such actions do not take place, which is reflected in the lack of relevant nodes in the graph of energy and emergy flow.

The influence of discontinuing the inflow of saline water and mowing during the renovation of the graduation towers, on the species composition and the abundance of individual components is presented in Figure 4. In the dendrogram drawn up with the UPGMA method, a lawn with a small contribution of halophytes and a high contribution
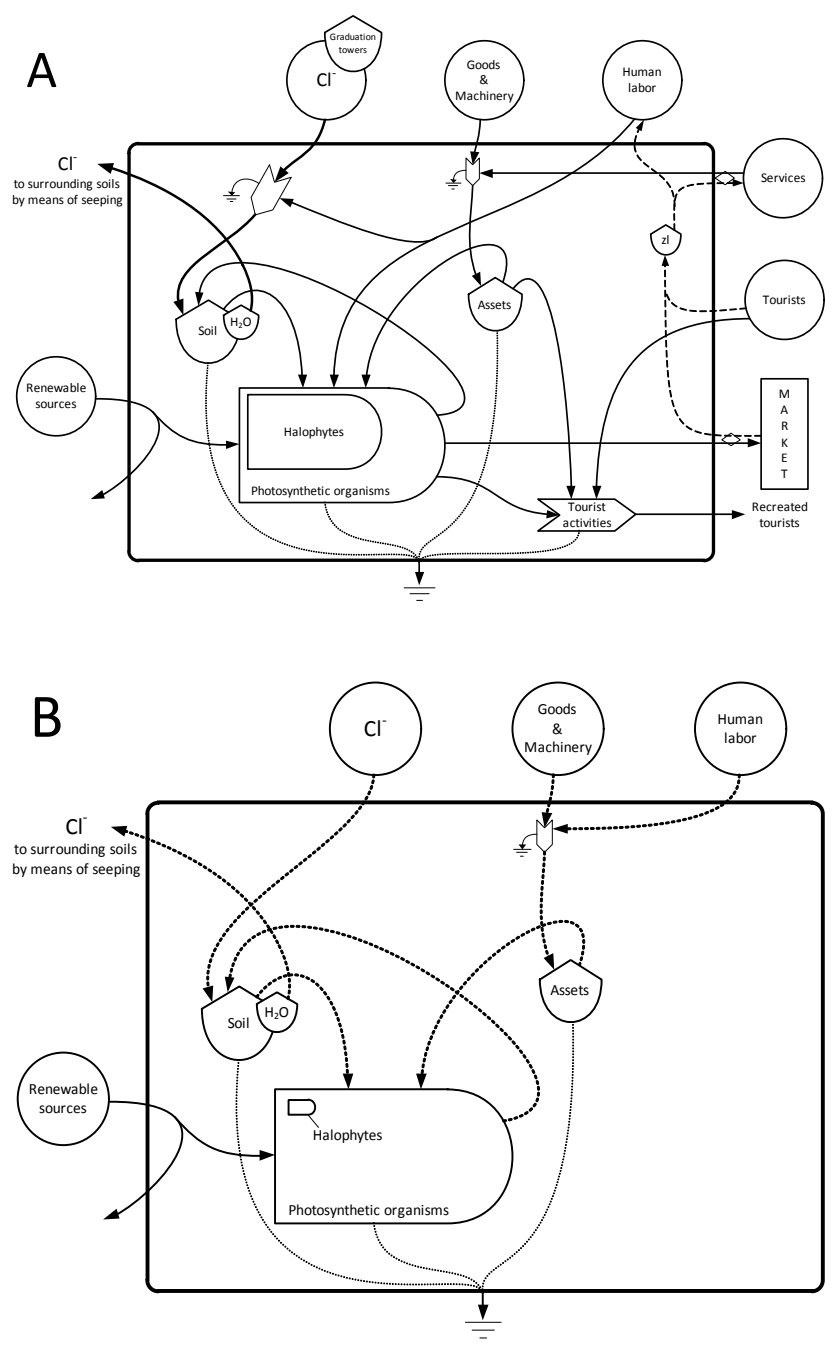

Figure 3. Diagram of emergy flow through the lawns near the graduation towers (A - with a functioning graduation tower, $\mathrm{B}$ - during renovation of a graduation tower)

of glycophytes, situated next to the renovated graduation tower no. 2 , is clearly different from the others.

\section{Conclusions}

The performed analysis confirmed that in order to preserve the halophytes, the continuous inflow of saline waters into the substrate is necessary. It also revealed that the human activity is necessary for the preservation as well. Sowing of traditional mixtures of grasses in the zones near the graduation towers is wrong. It is recommended to leave these lawns in the natural state, using extensive greenery nurturing methods. This will enable the succession of halophytes, as humid and saline habitats create favourable conditions for their development. Preservation of this group of plants 


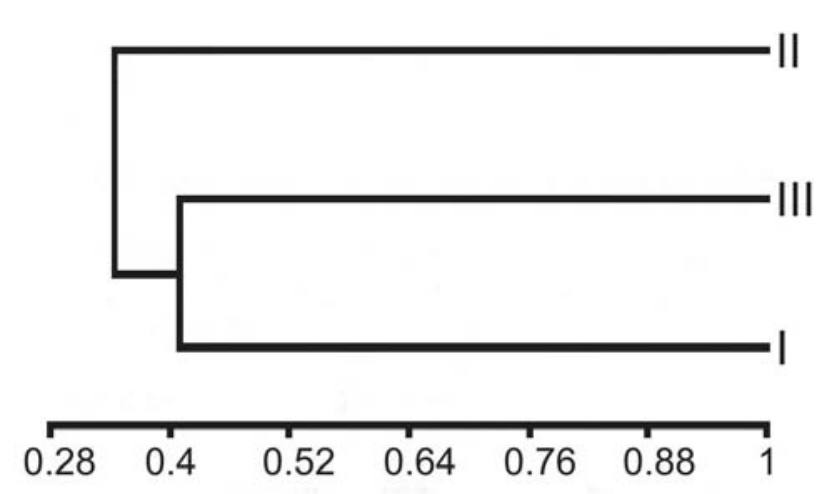

Figure 4. Dendrogram presenting the similarity between the flora of three lawns near the graduation towers (I, II and III), drawn up with the UPGMA method and applying the Jaccard's formula

within the zones near the graduation towers contributes to the improvement of aesthetic impressions made on numerous patients and tourists visiting the graduation towers.

Drawing up flow graphs with symbols of ,the energy language", introduced by H. T. Odum, is a very useful method to present the conceptual model of the human influence on the structure and functioning of salt marsh ecosystems. Diagrams presented above can constitute the basis for monitoring of the sustainability in the exploitation of communities with halophytes, according to the method proposed by Brown and Ulgiati (1997).

\section{References}

Brown M. T. \& Ulgiati S., 1997, Emergy-based indices and ratios to evaluate sustainability: monitoring economies and technology toward environmentally sound innovation, Ecological Engineering 9: 51-69.
Handziuk J., 1988, Roślinność rezerwatu halofitów „Ciechocinek” i trawników przytężniowych, praca magisterska [Vegetation in the reserve of halophytes "Ciechocinek" and the lawns near the graduation towers, Master's thesis, NCU, Toruń, in Polish], UMK, Toruń.

Marcykiewicz J., 2005, Roślinność trawników przytężniowych w Ciechocinku, praca magisterska [Vegetation of the lawns near the graduation towers in Ciechocinek, Master's thesis, NCU, Torun, in Polish], UMK, Toruń.

Nienartowicz A., 2007, Active protection of halophytes: Assessment of the human intervention range using the emergy analysis and indicators of sustainable development, [in:] M. T. Brown et al. (eds.), Emergy Synthesis 4, Theory and Applications of the Emergy Methodology, University of Florida, Gainesville: 8.1-8.12.

Odum H. T., 1996, Environmental Accounting: EMERGY and Environmental Decision Making, John Wiley \& Sons, Inc., New York-Chichester-Brisbane-TorontoSingapore.

Wilkoń-Michalska J., 1963, Halofity Kujaw [Halophytes of Kujawy, in Polish with English summary], Stud. Soc., Torun.

Wilkoń-Michalska J., 1970, Zmiany sukcesyjne w rezerwacie halofitów „Ciechocinek” w latach 1954-1965 [Plant succession in the halophyte reserve „Ciechocinek" between 1954-1965, in Polish with English summary], Ochrona Przyrody 35: 25-51. 